\title{
The Archaeology of the Streets of North Berwick and Implications for the Development of the Burgh
}

\author{
by Kirsty Dingwall
}

with a contribution by Julie Franklin

Headland Archaeology Ltd, 13 Jane St, Edinburgh EH6 5HE

Scottish Archaeological Internet Report 37, 2009 www.sair.org.uk 
Published by the Society of Antiquaries of Scotland, www.socantscot.org.uk with Historic Scotland, www.historic-scotland.gov.uk and the Council for British Archaeology, www.britarch.ac.uk

Editor Helen Bleck

Produced by Archétype Informatique SARL, www.archetype-it.com

ISBN: 9780903903639

ISSN: $1773-3803$

Requests for permission to reproduce material from a $S A I R$ report should be sent to the Director of the Society of Antiquaries of Scotland, as well as to the author, illustrator, photographer or other copyright holder.

Copyright in any of the Scottish Archaeological Internet Reports series rests with the SAIR Consortium and the individual authors.

The maps are reproduced from Ordnance Survey material with the permission of Ordnance Survey on behalf of The Controller of Her Majesty's Stationery Office @ C Crown copyright 2001. Any unauthorised reproduction infringes Crown copyright and may lead to prosecution or civil proceedings. Historic Scotland Licence No GD 03032G, 2002.

The consent does not extend to copying for general distribution, advertising or promotional purposes, the creation of new collective works or resale. 


\section{CONTENTS}

List of Illustrations and Plates.

iv

List of Tables

iv

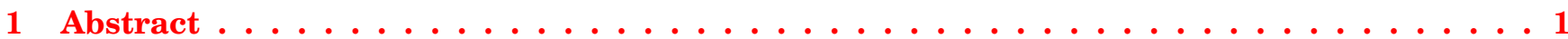

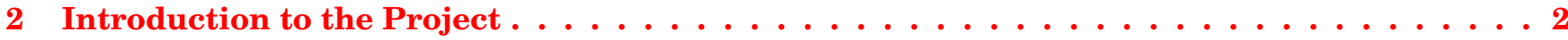

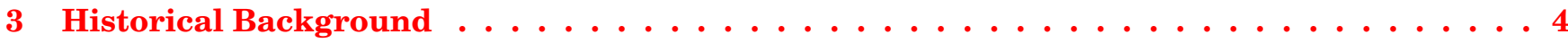

4 Archaeological Investigations in the Burgh $\ldots \ldots \ldots \ldots \ldots$

5 The Morphology of the Burgh $\ldots \ldots \ldots \ldots \ldots \ldots \ldots \ldots$

6 Pre-Fieldwork Potential of the Watching Brief $\ldots \ldots \ldots \ldots \ldots$

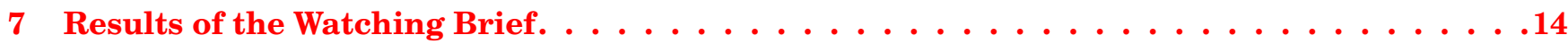

7.1 Introduction . . . . . . . . . . . . . . . . . . . . . . . 14

7.2 Sediment depth and character . . . . . . . . . . . . . . . . . . . 14

7.3 Archaeological structures and features . . . . . . . . . . . . . . . . . . . 17

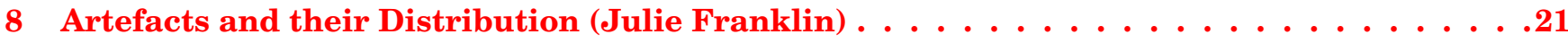

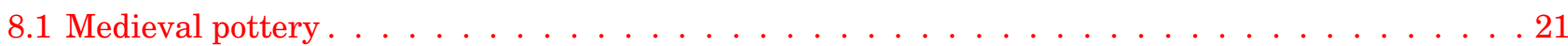

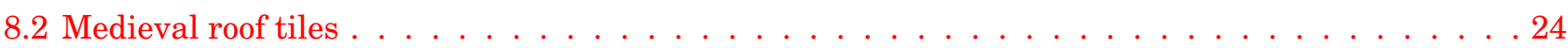

8.3 Later pottery and finds . . . . . . . . . . . . . . . . . . . . . . . 24

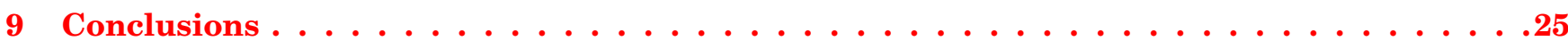

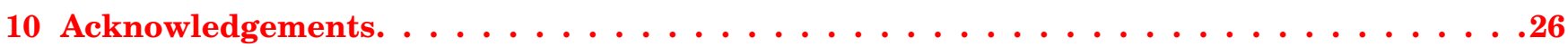

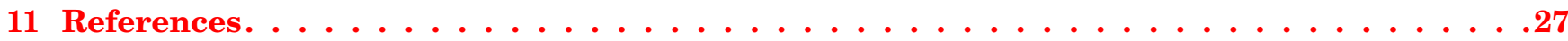




\section{LIST OF ILLUSTRATIONS AND PLATES}

1 Trenches monitored during watching brief . . . . . . . . . . . . . . . . . . . . 3

2 OS 1st Edition - Reproduced by permission of the trustees of the National Library of Scotland . .5

Previous interventions. . . . . . . . . . . . . . . . . . . . . .

Adair's map - Reproduced by permission of the Trustees of the National Library of Scotland . . .9

Map regression. . . . . . . . . . . . . . . . . . . . . . . . . 10

Medieval core. . . . . . . . . . . . . . . . . ........13

Selected features. . . . . . . . . . . . . . . . . . . . . . . . 15

Sample section High St . . . . . . . . . . . . . . . . . . . . . . . . . 16

Sample section East Rd . . . . . . . . . . . . . . . . . . . . . . . . 18

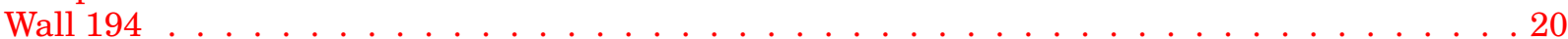

Details from finds . . . . . . . . . . . . . . . . . . . . . . . 21

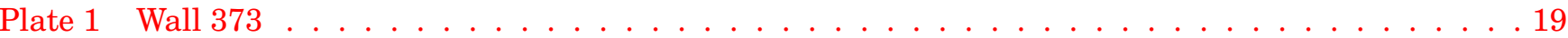

\section{LIST OF TABLES}

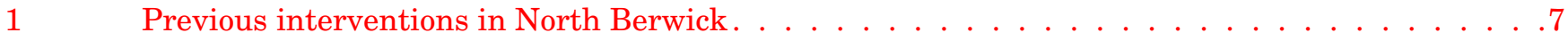

2 Pottery sherd count (ordered by street/trench) . . . . . . . . . . . . . . . . 22 


\section{ABSTRACT}

Replacement and upgrading of the mains water system in North Berwick provided an opportunity to identify and record deposits and structures across the core of the medieval burgh. The methods of trench excavation used meant that archaeological features were largely only seen in section, however, a large amount of information about the development of the burgh, and its layout, was collected despite this. Over much of the central core of the medieval burgh, layer upon layer of occupation deposits and more mixed material were interspersed with obvious inundations of wind-blown sand. The existence of a rough surface running east-west along much of the High Street could suggest that this is the more likely candidate for the earliest focus for the burgh, rather than the north-south running Quality Street further to the east. Road surfaces were also seen along East Road, running out of the town. The density of occupation deposits markedly lessened along Westgate, the continuation of the High Street, indicating the limits of the medieval core. A number of structures were also identified, including a wall at the east of the town that may represent the 'town wall', or at least define the limit of settlement to the east. The data collected from the watching brief will allow better assessments for future planning decisions, and also shows the importance of archaeological monitoring of this type of construction work. 


\section{INTRODUCTION TO THE PROJECT}

Recent work in North Berwick has identified deeply stratified well-preserved deposits relating to the medieval and post-medieval development of the town, along with elements of structures and surfaces. The scale of the work allowed deposits to be recorded throughout the core of the medieval town, within the harbour, and towards the nunnery to the west, giving a more complete view of the archaeology of the burgh than was previously possible.

The watching brief was undertaken during works to upgrade the mains water supply within the town. Prior to excavation, areas of sensitivity or of unknown potential were identified, using previous work as a guide (Turner Simpson \& Stevenson 1981; Hall \& Bowler 1997). Excavation within these areas was then monitored. All trenches (illus 1) were monitored, with the exception of the section of Quality Street between the High Street and Kirk Ports, which was excavated and backfilled without archaeological supervision.

Although the trenches monitored were excavated throughout the core of the burgh, detail of deposits and features were only clearly defined through examination of sections, due to the narrow nature of the trenches. This provided a good picture of the types, range and distribution of deposits in the burgh, but meant that it was more difficult to make an interpretation of individual cut features or structures.

The results of the watching brief are presented here, and the known evidence of the morphology and fortunes of the burgh are then reconsidered in light of these and other recent work in the burgh. 


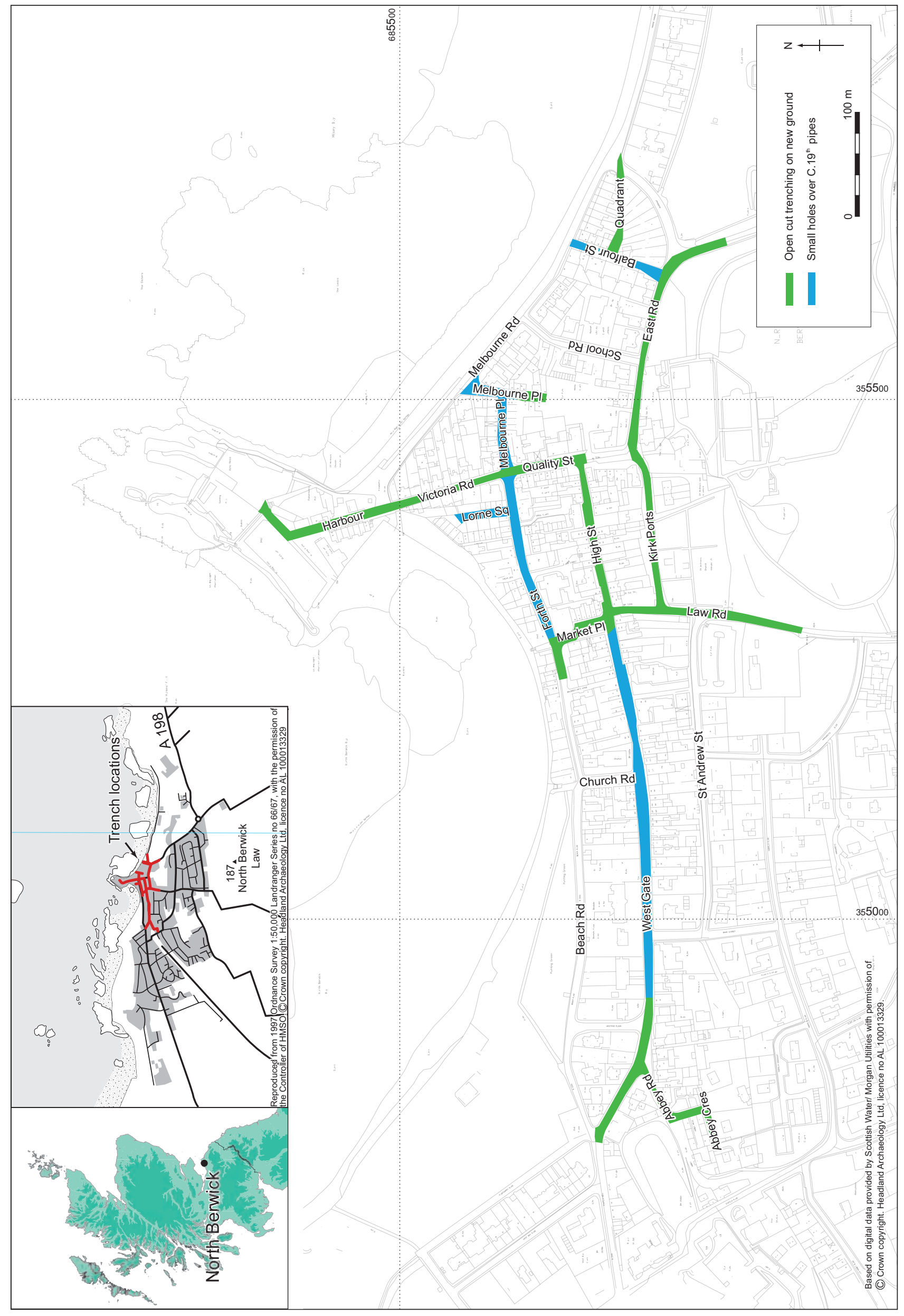

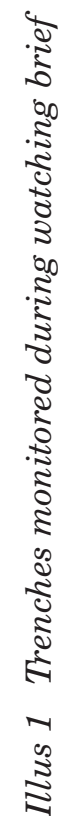




\section{HISTORICAL BACKGROUND}

North Berwick is situated on the east coast of Scotland, overlooking the Firth of Forth. Together with Haddington and Dunbar, it is one of three royal burghs in East Lothian. The town began in the medieval period and grew to be one of the major settlements in the centuries following. In the later medieval period its fortunes fell and it remained this way until the arrival of the railway and its transformation into a popular seaside destination.

The origins of the burgh are unclear. The earliest records indicate that North Berwick as a settlement was certainly in existence by the reign of David I (1124-53). The Earls of Fife were given the lands and manor of North Berwick at this time, and it is thought that Duncan I, Earl of Fife (1136-54), founded a nunnery there between 1147 and 1153 . An early church of St Andrew is known to have existed near the current harbour, and this is likely to date from this period, or even earlier. The church at the harbour was intended to serve the pilgrims who travelled from this point over to Earlsferry in Fife on their way to St Andrews. The first written record of St Andrews as a place of pilgrimage is in the 10th century (Yeoman 1999, 53), but it is not known exactly when the route from North Berwick to Earlsferry was established. It has been claimed that a ferry port for pilgrims was in existence from the 8th century (Turner Simpson \& Stevenson 1981, 14) and recent excavations (Addyman forthcoming) at the site of the medieval Church of St Andrew at the harbour should shed more light on this and the origins of the church.

The earliest documentary evidence of North Berwick dates from 1177, in a document where the chaplain of St Andrew's Church in North Berwick is a witness. In 1199 the church, along with the hospital and other areas of land, was confirmed as the property of the nunnery by Malcolm, Earl of Fife. North Berwick's status as a burgh is known from the 14th century onwards, although initially it was a baronial burgh linked to the Douglas family; the first Earl of Douglas had the right to have a port and erect a custom-house and a tron, given by Robert II in 1373 (New Statistical Account (NSA) $1845,323)$. It had been made a royal burgh by the reign of James I (1406-37) and appears in various official documents throughout the 15th and 16th centuries.

The burgh would originally have benefited from its position as the crossing point for the ferry on a major pilgrim route, although in the late 11th century Queen Margaret had given permission for another pilgrims' ferry across the Forth further upstream (at 'Queen's Ferry'). This would undoubtedly have taken away some of the trade that the pilgrims provided and the fortunes of the town may have declined as a result. However, the fall of Berwick-on-Tweed, one of the largest trading burghs in Scotland, to the English in 1333, meant that North Berwick and the other burghs of East Lothian (Dunbar and Haddington) benefited and took this share. In fact, North Berwick had the largest share of trade of these three towns.

By the 17th century the fortunes of the town appear to have been on something of a downturn. St Andrews' position as a focus of pilgrimage had begun to wane in the 16th century (Yeoman 1999, 69) and the development of Queensferry as the favoured route, perhaps because it also allowed pilgrims to visit St Margaret's shrine in Dunfermline, had also taken its toll.

Despite North Berwick's share of the trade from Berwick-on-Tweed, the rival towns of Haddington and Dunbar began to take over as the main trading towns in the area. The levels of taxes paid by Dunbar in the 16th century were regularly two to three times that of North Berwick, and this continued into the 17th century (Turner Simpson \& Stevenson 1981,2). Additionally, North Berwick no longer had a market or fair by the end of the 17th century, as in 1695 parliament attempted to revive these activities. It is also thought that a proper harbour was never constructed by the Earl of Fife, and this certainly seems to be confirmed by the fact that the town had only two fishing vessels in 1692 (Turner Simpson \& Stevenson 1981, 3). It is interesting to note that St Andrews appears to suffer a similar decline around the same time (Rains \& Hall 1997, 3).

Visitors to North Berwick confirm the status of the town in the 18th and early 19th centuries, describing it as 'illbuilt' and 'melancholy' (Turner Simpson \& Stevenson 1981, 3), and also indicate that there was no great trade or manufacture in the town. It was only in the second half of the 19th century that the situation of the town began to improve, with the presence of a railway line from Edinburgh bringing visitors and improving access. A foundry was constructed at the east end of town during this time (Ordnance Survey 1854, illus 2), evidence of the improvements that the railway provided. 


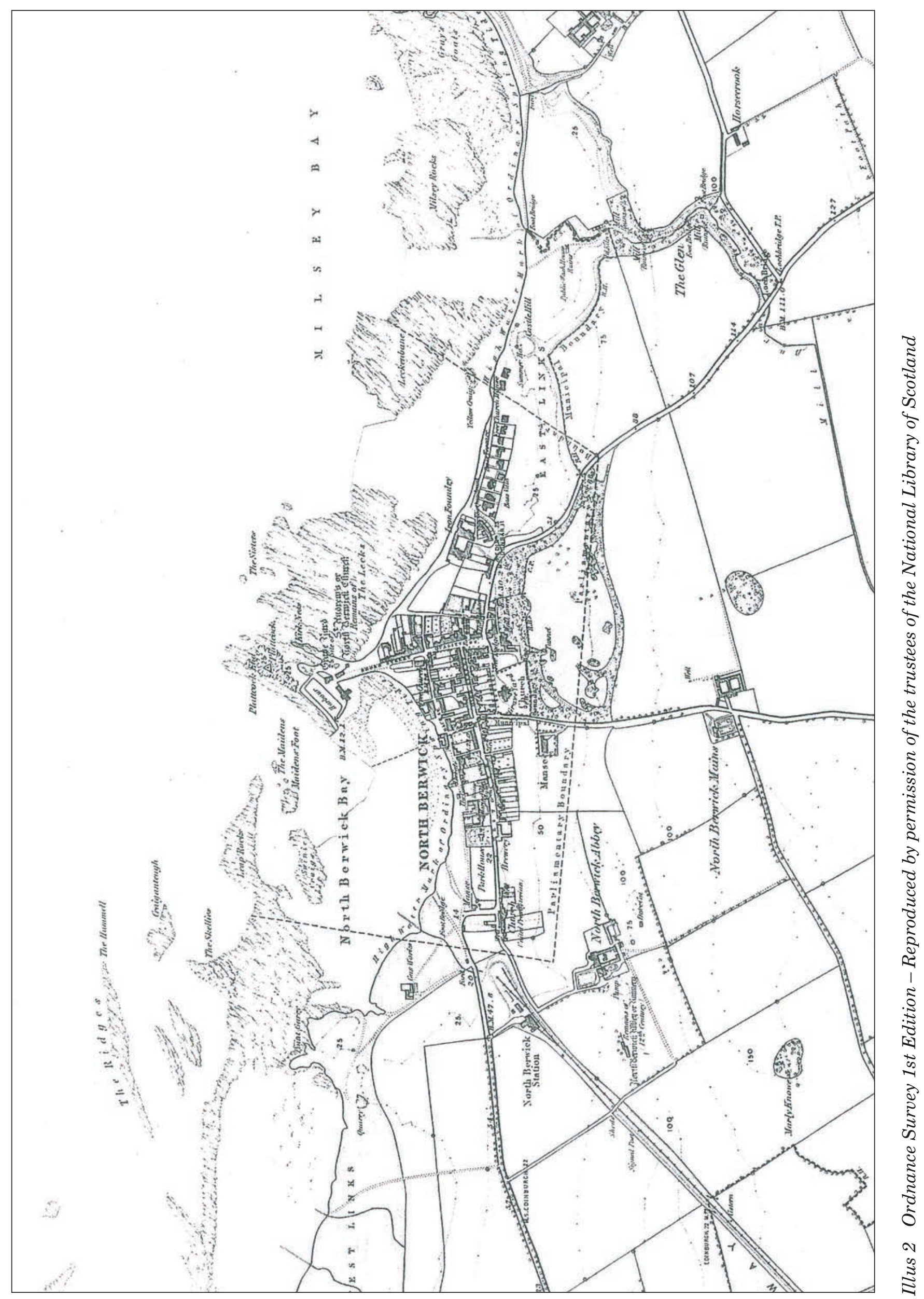




\section{ARCHAEOLOGICAL INVESTIGATIONS IN THE BURGH}

Since the first Scottish Burgh Survey of North Berwick was produced (Turner Simpson \& Stevenson 1981), there have been two substantial updates. A general discussion of this, along with a record of all work in the intervening period, was provided in Derek Hall and David Bowler's work (Hall \& Bowler 1997, 672-74), and an update to the Burgh Survey was undertaken by SUAT the following year (SUAT 1998). Table 1 provides a further expansion of this work, with all interventions and finds in the burgh core and area of the nunnery to date.

It should be noted that in the last decade, there has been an increasing amount of archaeological investigation within the burgh, ranging from watching briefs to full excavations. The main areas that have been investigated are two separate sites on Forth Street (illus 3, sites 1 and 2), the site of St Andrew's Old Church on the harbour (illus 3, site 3 , various investigations in and around the site of the nunnery to the west of the burgh (not shown) and a number of smaller interventions on the High Street and Quality Street (illus 3, sites 5, 6, 7, 8, 12, $14,16,19)$.

The work undertaken by Addyman Associates at St Andrew's Old Church since 1999 is undoubtedly the most substantial and is likely to provide important new information relating to the early origins of the burgh in particular. The results of this work are not currently published, but initial reports indicate that deposits predating the known 12th- century church were identified (Addyman 2000, 27-8 and Macfadyen 2004, 45-6; illus 3, site 3).

Further work on the important structures in the medieval core was undertaken at the supposed site of an almshouse on Quality Street, near the junction with Melbourne Place (Mackenzie 1995, 50 ; illus 3 , site 8 ). The site was heavily truncated due to the presence of underground petrol tanks, and no evidence to confirm or deny the existence of the almshouse was identified. However, thin layers of midden and garden soil of medieval date were identified.

There have been a number of smaller-scale interventions along the High Street (illus 3, sites 7, 12, 19, 4, 5, 6, 21) and St Andrew Street (illus 3, sites $22,9,10$ and 20), which illustrate the nature of survival of deposits within the burgh. In many cases no substantial archaeological deposits were encountered, while in certain cases, evidence of medieval and post-medieval stratified deposits were identified. These tend to take the form of sandy midden deposits, sometimes interspersed with wind-blown sand deposits.

As the investigations have largely been within the extents of burgage plots (in gardens of existing houses or within the sites of demolished buildings), the results so far collected tend to relate to activities which would have taken place in the backlands, eg the kiln found on Forth Street, or the clay-lined pits found on the High Street. 
Excavations

Location Description

No. on illus 3

Forth Street Lane

Trial trenching in 1993 by SUAT. Deposits were seen to a depth of $2.5 \mathrm{~m}$. Evidence of 1 structures relating to the High Street frontage were seen, as were organic deposits, sealed by layers of wind-blown sand. A medieval drying kiln was also present.

33 Forth Street CFA excavation in 2003-04 identified 6 phases of activity, including several phases 2 of midden deposit, wind-blown sand layers and stone structures.

St Andrew's Old

Kirk

Early excavations and surveys of the old church undertaken in the 19th century $3 \mathrm{a}$ and mid 20th century. Pilgrim badge mould recovered.

St Andrew's Old

Excavation of early church by Addyman in 2000 and 2004/5. Results not yet published but may include material of Anglian date, and certainly contains premedieval material.

71 High Street Excavation of plot by Addyman/David Connolly revealed up to 2m of deposits.

St Andrew's Black- Excavation by SUAT revealed garden soil and cobbles to the south of the High adder Church

Nunnery Street.

Nunnery

Excavation by AOC uncovered 6 burials adjacent to the abbey and a structure Tile kiln excavated in 1930s.

\section{Evaluations}

83-7 High Street

Trial excavations by SUAT in 1987 identified two circular clay tanks. It has been suggested that they may have been for use during the malting process, however only minimal amounts of grain were found.

18-24 High Street SUAT trial excavations in 1990 identified organic medieval material to a depth of $2 \mathrm{~m}$ and a clay bonded structure. There were also layers of wind-blown sand.

Dalrymple Garage, Quality Street Investigations by SUAT in 1995 identified thin bands of midden and wind-blown 8 sand containing 12th-13th-century pottery.

Abbey Church Hall Excavation of structure known to have been ruined by the mid 19th century, 20 along with cobbling belonging to pend. Structures overlay deep stratified deposits, including wind-blown sand.

St Andrew Street Test trenches by the CFA identified at least two cist burials containing bone, and an iron knife and brooch.

7-9 St Andrew

Street

Trial trenching by CFA in 2003 identified a probable medieval buried garden soil. 10

East Lothian Yacht Trial trenching by CFA in 2002 identified no remains of archaeological

Club significance.

19-21 High Street

Evaluation by AOC identified 18th-century building and associated garden soil, overlying deposits of unknown function to a depth of $2 \mathrm{~m}$.

Scottish Seabird

Addyman Associates assessed the basement of the Scottish Seabird Centre

Not shown

Centre

Law Rd/St Andrew

St

Test trenching revealed deep deposits of sterile sand, thought to have been dumped here. No archaeological features were identified.

Old Abbey Road

CFA evaluation at proposed building site identified areas of medieval remains under layers of medieval demolition and garden soil.

\section{Watching briefs}

15 Westgate

SUAT watching brief identified $2 \mathrm{~m}$ of garden soil with no other features of

St Andrew's

Churchyard archaeological interest.

NMS monitoring of removed churchyard soil identified disarticulated human

2 Quality Street

SUAT watching brief in 1994 identified garden soil to a depth of $0.7 \mathrm{~m}$ and a recent 16 stone-lined well.

7 Victoria Road SUAT watching brief in 1995 identified mixed sand and early modern pottery.

St Andrew's Old Kirk SUAT watching brief during consolidation work identified one inhumation and details about the construction of the early church.

63-65 High Street Headland Archaeology watching brief reached deposits containing medieval pottery and a surface at the bottom of a sondage.

30 High Street Watching brief by Headland Archaeology identified garden soil and wind-blown sand.

Old Abbey Road

CFA watching brief at site of previous evaluation identified medieval deposits, structures and artefacts. 


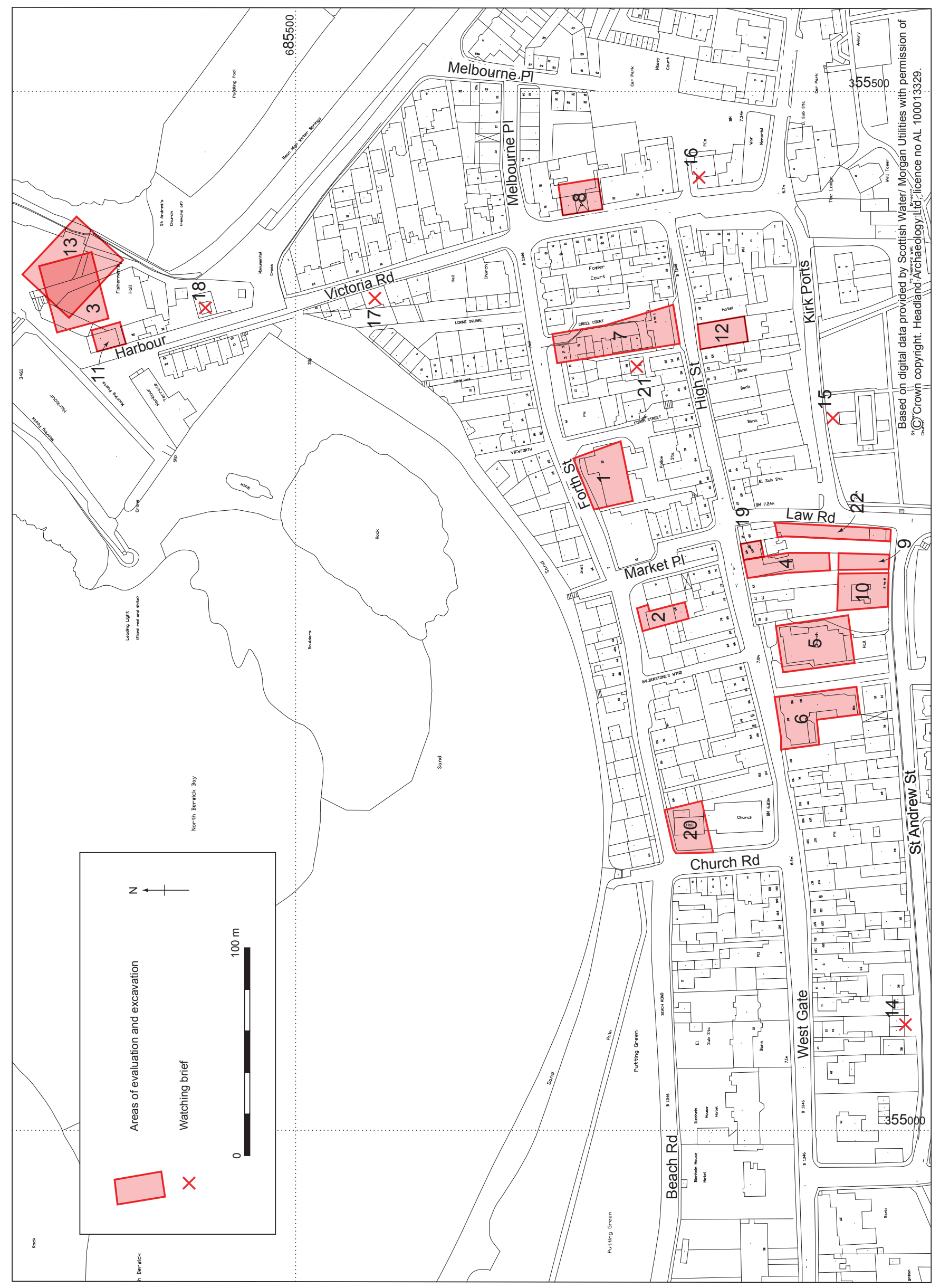

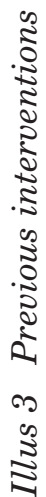




\section{THE MORPHOLOGY OF THE BURGH}

The current layout of the town can be described broadly as having two main axes, one running eastwest (comprising the High Street and Westgate), and one running south from the harbour, which also includes Victoria Street and Quality Street (illus 3). There are additional streets that developed to the north and south of the High Street axis, and further development to the east of Quality Street. One of the most interesting questions about the growth and layout of North Berwick relates to which of these two streets emerged first.

A study of the early maps of North Berwick goes some way to giving an understanding of how the town grew. The earliest known map from 1630 (credited to Pont, and published by Hondius) shows the nunnery to the west of the town, surrounded by a wall of some kind. What appears to be a single line of buildings runs to the east of this. At the east end of this is a larger building (either the tron or a church) although no specific indication is given of the ferry port at the harbour. Blaeu's map from 1654 , which is a more formal version of Pont's information, also shows the same layout, with no greater degree of detail. This is clearly the present High Street. The fact that it appears to run all the way up to the boundary of the nunnery is of some interest, suggesting the two elements were closely linked.

The first map to show the town in any degree of detail is Adair's map from 1682 (illus 4). This also shows the nunnery to the west of the town, although it does not seem to be so dominant in comparison to the town as it does in Pont's map. There are then buildings lining the north and south side of a single road, with a slightly larger open area at the east end, also surrounded by buildings. A cross is marked at the centre of this area, and is likely to be the market cross, or possibly the tron. Roughly halfway along the main street on the north side the church is marked, sitting on what appears to be a small island or peninsula, partially joined to the mainland. Immediately to the west of this island, an anchorage or harbour is noted. This arrangement implies that the main original street was on an eastwest axis. However, the open space at the east end and presence of a market cross here (the supposed location of which has survived into modern memory) suggests that the focus of town life - the market cross, tollbooth and tron (Hall \& Bowler 1997, 667) was very definitely at the east end of that axis. In fact Quality Street was known as Market Place and Crossgate until relatively recently (Turner Simpson \& Stevenson 1981, 4).

Adair's map also suggests that the north-south street (such as it exists on this early manuscript version) does not line up with the harbour and church. The layout is repeated in the more formalised printed version published in 1736. None of the later maps of North Berwick show this arrangement, and it is more than likely that it is merely a schematic representation.

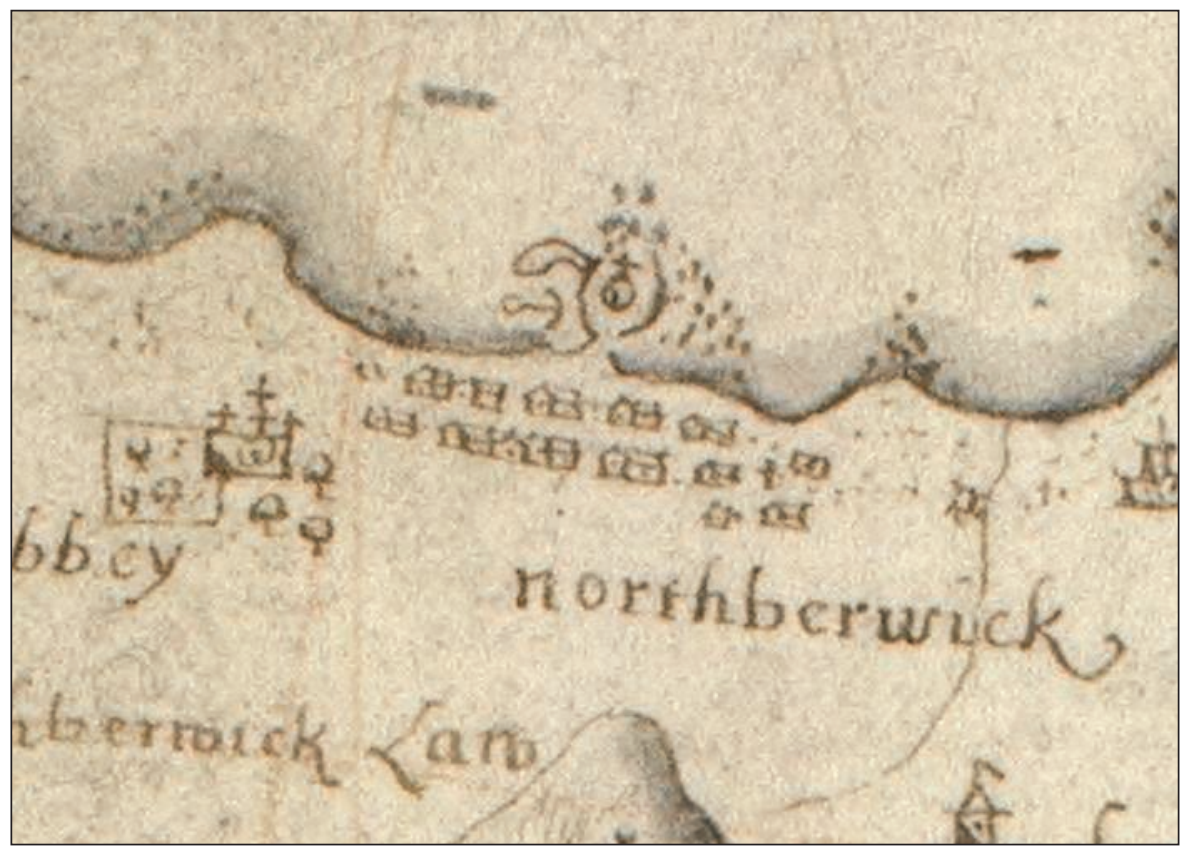

Illus 4 Adair's map-Reproduced by permission of the Trustees of the National Library of Scotland 


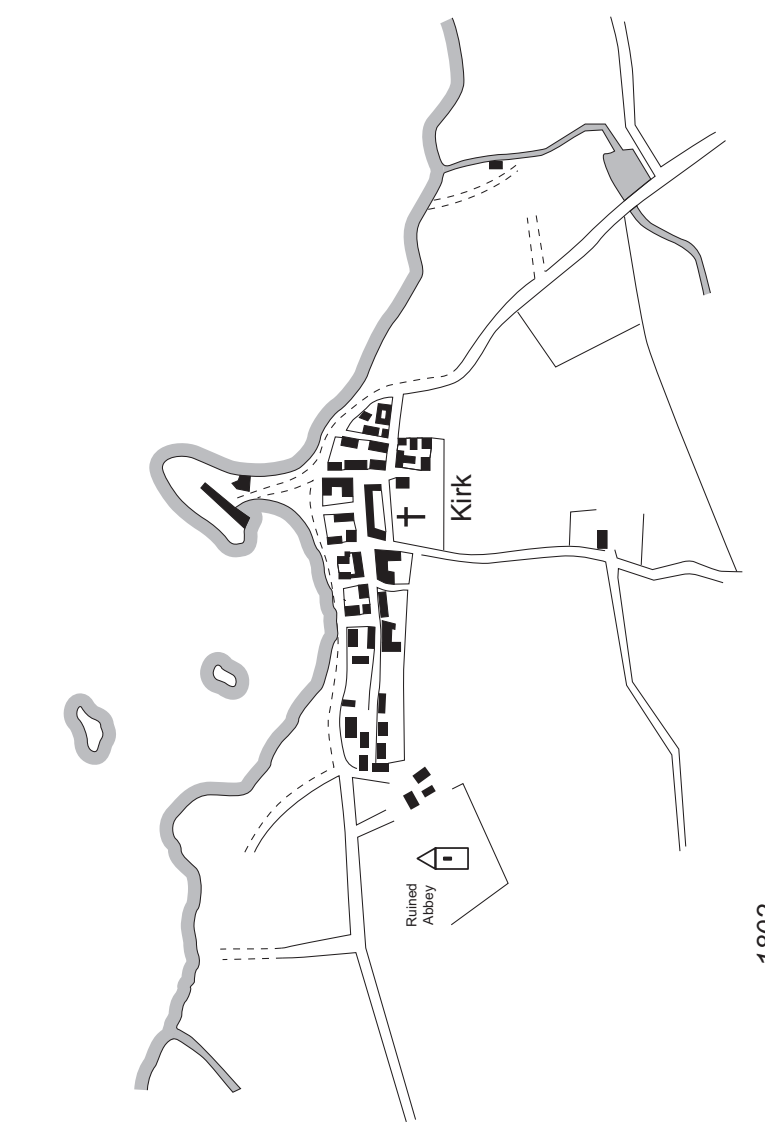

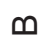

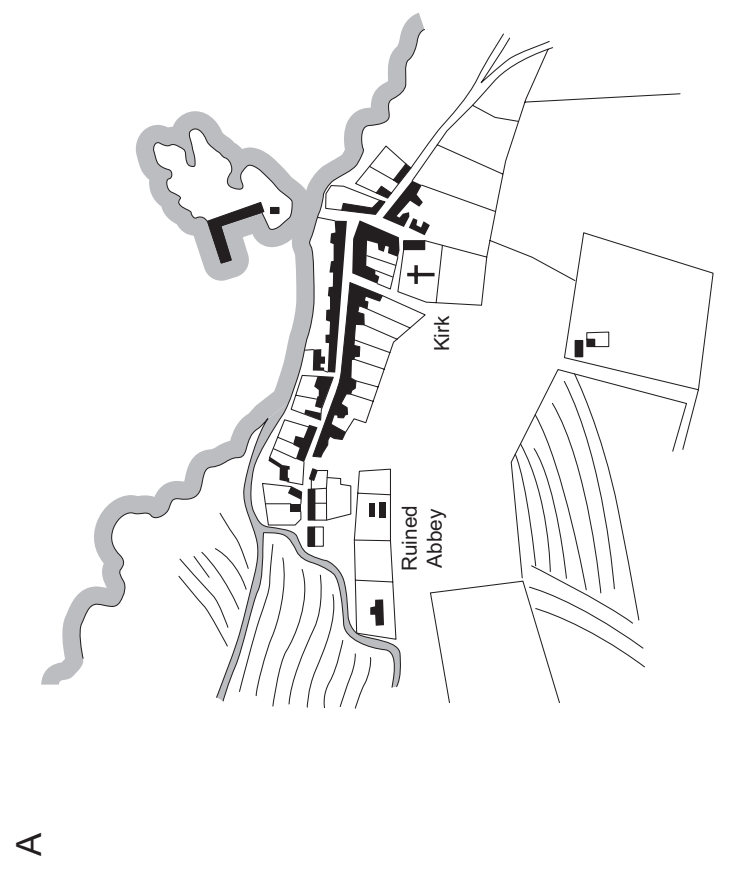

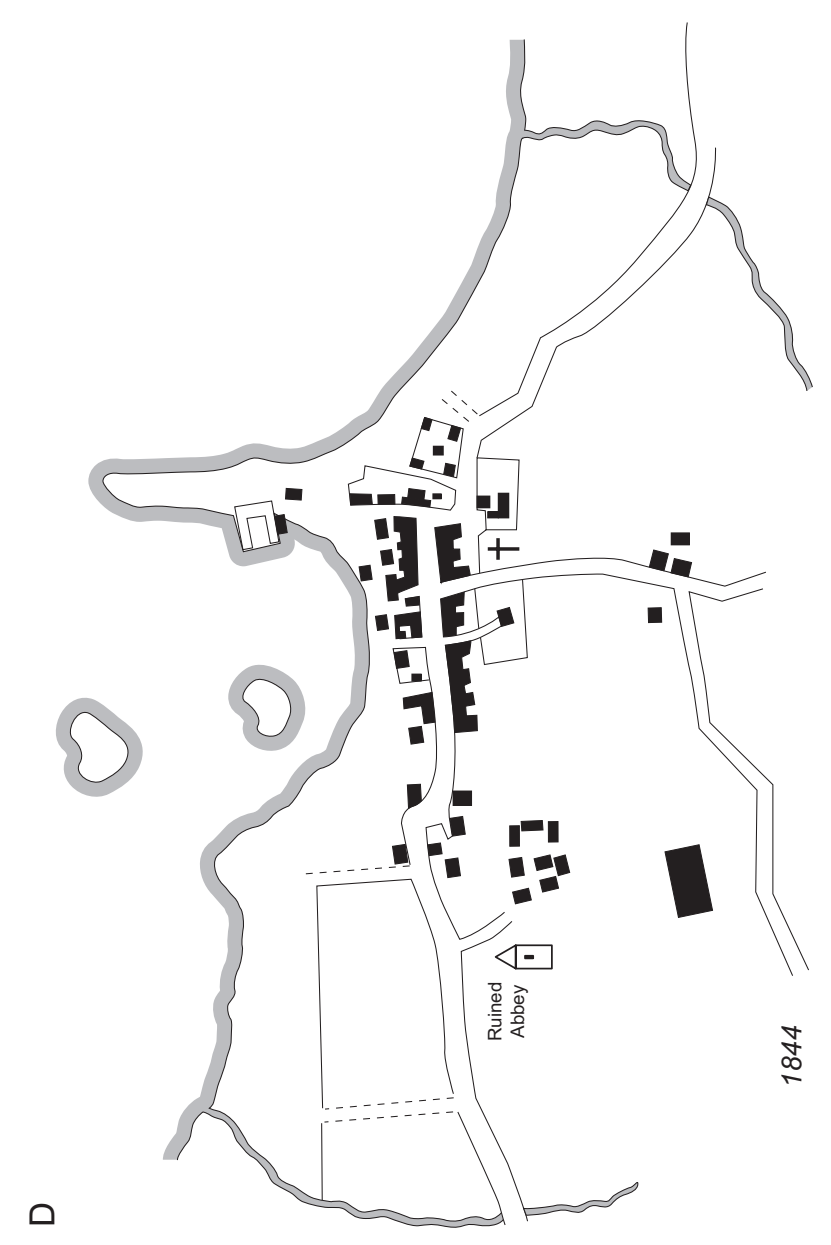

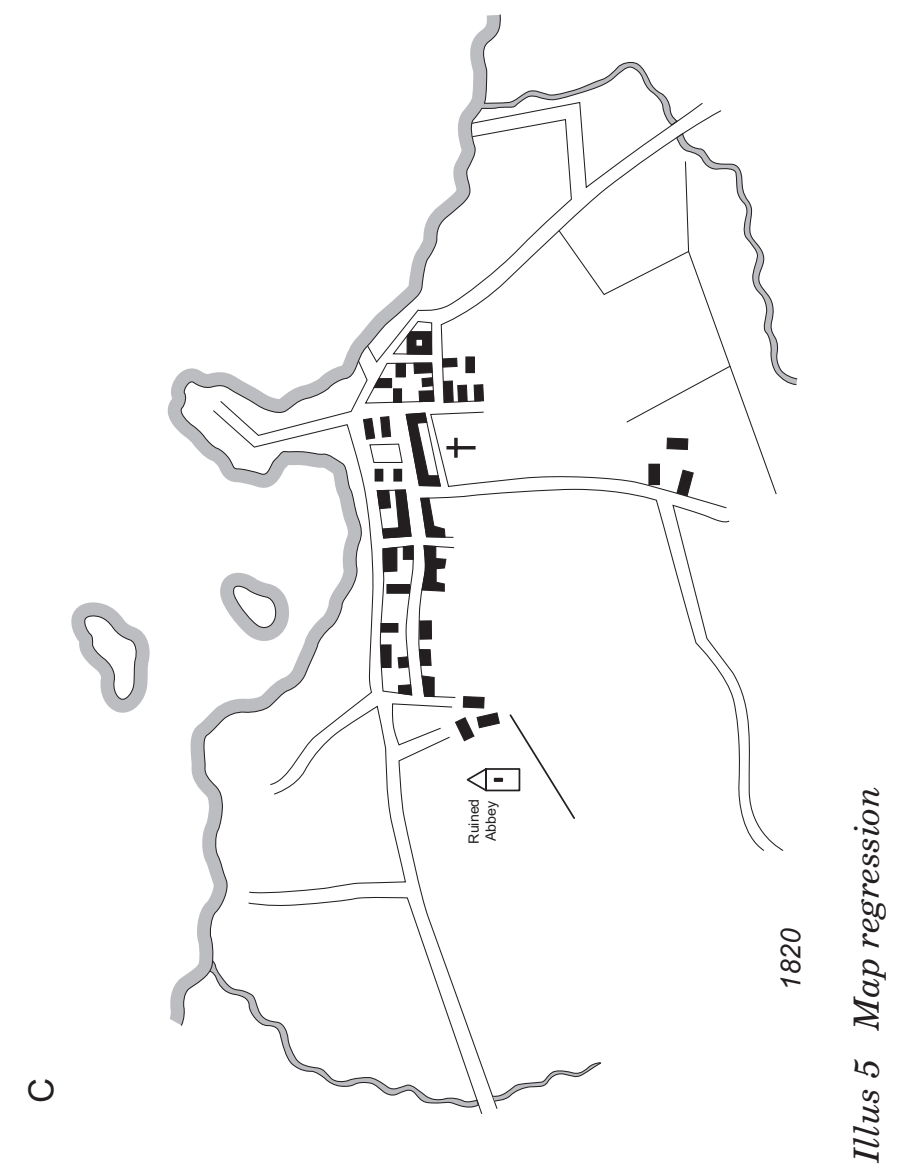


The next key map is Roy's Military Survey (illus $5 a)$ of the mid 18th century which shows the plan of the town in great detail, with the High Street aligned east-west and Quality Street crossing this at the east end, running north-south towards the island harbour. This map indicates clearly the narrow plots running back from the main street, and also shows that the plots on the north side of the street extend right down to the beach, although a small lane is apparent at the west end of the beach (presumably the forerunner of the present Beach Road). The church on the island harbour is no longer marked, and a new one is shown to the south of the main street. Documentary evidence indicates that the church at the harbour had become ruined by 1656 (Ferrier 1991, 49) and a new one was built in the following decades. The new location was such that the church may have been built on land that was previously occupied by backland plots running south from the main road. The plots to the north can be seen to have been truncated, and the southern wall of the churchyard appears to line up with the southern wall of the plots to the west. Another new insertion is the north-south road immediately to the west of the church (the future Law Road), presumably constructed to allow access to the new church.

Roy's map also shows a reasonable level of settlement at the western end of the town, reaching almost as far as the old nunnery. There are certainly fewer buildings at this end of the town, but some degree of activity is taking place.

There are a number of maps from the early 19th century that show a few changes to the town, although no substantial differences take place in the general layout. The main differences relate to the harbour and to the development of the back lanes such as Forth Street and St Andrew Street. The existence of Forth Street is first suggested in Forrest's map of 1802 (illus 5b), where the dotted outline of it can be seen. Thomson's map of 1820 (illus 5c) shows a more formalised road layout and Sharp, Greenwood \& Fowler's map of 1844 (illus 5d) shows the presence of buildings along the north side of the road, although not the road itself. A similar thing happens later in the 19th century with the emergence of St Andrew Street and the realignment of Kirk Ports. Roy's map from the mid 18th century shows a narrow lane to the north of the new church - this is Kirk Ports. To the west of this, however, the burgage plots extend in line with the back wall of the churchyard. This continues to be the case until the second half of the 19th century, with St Andrew Street shown for the first time on the second edition Ordnance Survey map from 1894. The improved harbour complex appears for the first time on the parliamentary boundary map from 1832. The deepened harbour was built in 1804 (Ferrier 1991, 64), and work also involved building up the road from the harbour 'island' (which had been joined to the town for some time) to Quality Street. The built-up part of the road was named Victoria Street later in the century.

The map evidence would seem to suggest it is more likely that the High Street is the original main street of the burgh, although the east end of it was where the 'burgh activity' took place. Presumably this layout emerged as a result of the presence of the ferry at the harbour, along with the influence of the nunnery to the west of the town.

The medieval core can be roughly defined as a result of the documentary and map evidence. The extents roughly follow Melbourne Place, through the current car park to the south of this, then running behind the lodge at the end of Quality Street, along the southern wall of the 17th-century church, continuing this line on the south side of St Andrew Street and then turning north at around Church Road, then running down to the beach (illus 6). Previously, St Andrew Street itself was thought to mark the southern boundary, but the long plots to the south of the High Street appear to extend as far as the church boundary, or certainly further to the east (illus 5a).

In addition to the main issue of establishing the primacy of the High Street or Quality Street in the origin of the town, the other main issue is that of the town walls. All towns of Scotland on the east coast were required by an Act of Parliament of 1503 to build stone walls. Evidence of these walls has never been found in North Berwick, nor any further documentary references to such structures. Blaeu's map of 1654 shows an enclosing structure to the west of the town (probably around the grounds of the nunnery), and Roy's map of the mid 18th century depicts the plot divisions to the east of Quality Street, but there is nothing that could be described as a town wall. If such walls did exist, the map evidence suggests that it is likely that they would be located in the vicinity of Church Rd and Melbourne Place - to the west and east respectively and along St Andrew St to the south. 


\section{PRE-FIELDWORK POTENTIAL OF THE WATCHING BRIEF}

Prior to the watching brief taking place, areas of sensitivity were identified, largely based around the medieval core of the town (illus 6). The areas monitored focused on the High Street/Westgate and Quality Street/Victoria Road axes, including the subordinate roads to the north and south of the High Street and the numerous smaller lanes linking these routes.

The potential of the watching brief to encounter in situ remains was high, along with the possibility of resolving issues such as the existence of town walls, the location of the town market, and the primacy of either the High Street or Quality Street. A similar watching brief at Crail (Lowe 2001, 93-109) revealed a broad range of deposits, artefacts and structures and there was the potential that the works at North Berwick could similarly throw light on the town's development. 


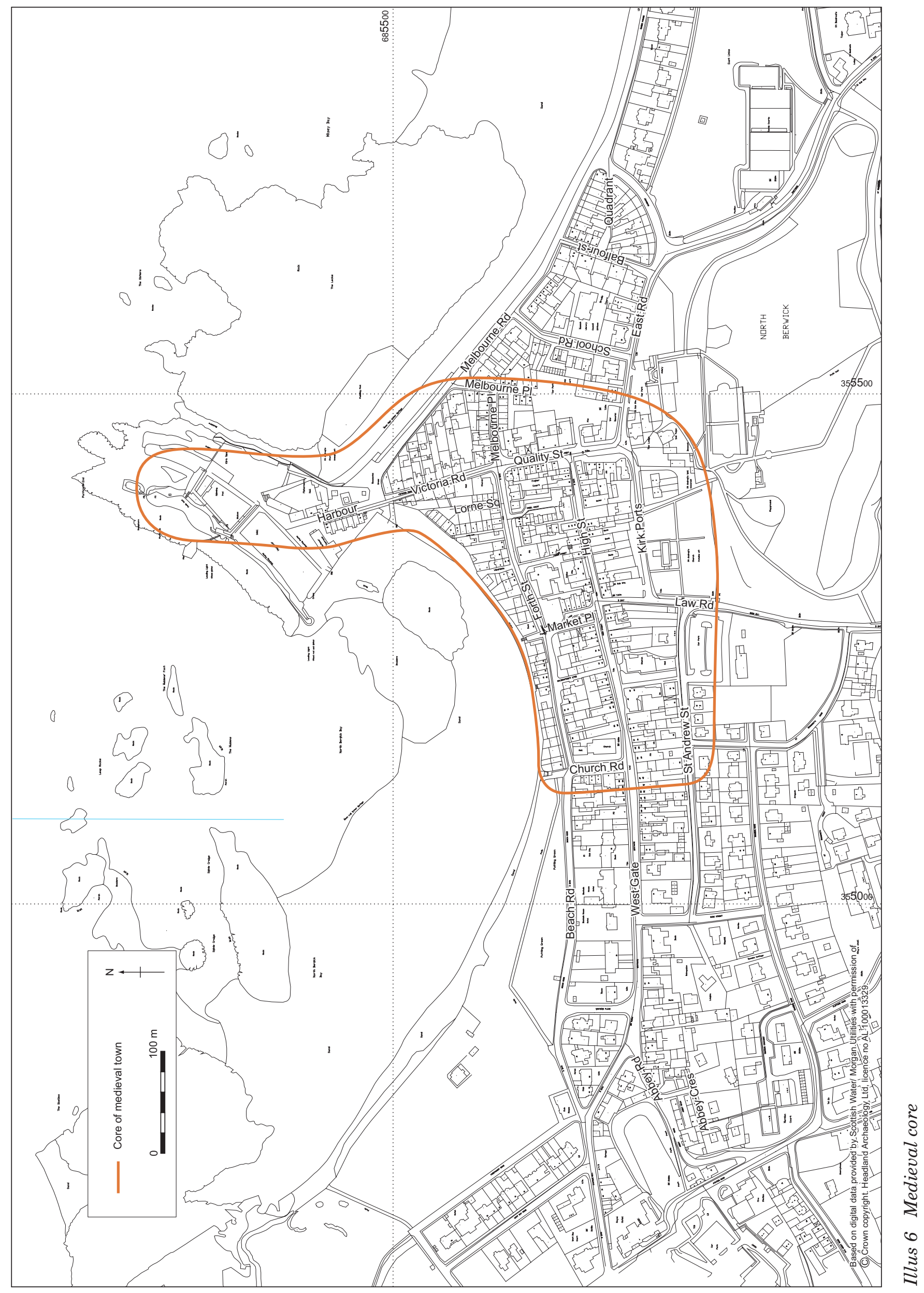




\section{$7 \quad$ RESULTS OF THE WATCHING BRIEF (Illus 7)}

\subsection{Introduction}

The replacement of the entire mains water system afforded the opportunity to get an insight into the survival, depth and characteristics of typical deposits throughout the core of North Berwick. Due to the condition and nature of the existing water pipes, a range of methods was used by the engineers, which then had an effect on the extent of deposits observed (illus 1 shows the different methods of excavation used on each street). For example, for much of Forth Street, the new pipes were inserted through existing cast-iron pipes, meaning that a series of small holes was excavated directly over 19th-century pipes. Therefore these trenches largely encountered only 19th-century backfill. It is interesting to note that even in these cases the survival of narrow sections of in situ deposits was higher than expected. The effect of this on the potential for further similar watching briefs is discussed in more detail below.

\subsection{Sediment depth and character}

Where continuous deposits were identified, sections were drawn (either sample sections every few metres or continuous sections, depending on the complexity of deposit). In general, the trenches were between $1 \mathrm{~m}$ and $1.4 \mathrm{~m}$ in depth, and natural subsoil was largely not encountered at these depths. The exceptions to this were in trenches on Law Road, where bedrock was encountered at a depth of $0.9 \mathrm{~m}$, rising to $0.3 \mathrm{~m}$ below the surface in places, and on East Road, where an outcrop of bedrock was seen at $0.6 \mathrm{~m}$, at the far west end of Westgate and on Melbourne Place, where beach sand was encountered at the base of a trench. However, in almost all cases where stratified material survived, it was over $1 \mathrm{~m}$ in depth. This has also been seen in other excavations in North Berwick, on a SUAT excavation on Forth Street (Cromwell 1993, 56), and CFA's site on Forth Street proving a particularly rich example (Mitchell 2004, 11), with at least $2 \mathrm{~m}$ of deposit and six definable phases of activity.

\subsubsection{High Street, Quality Street, Market Place (medieval core)}

Deposits resulting from general occupation debris were identified over much of the medieval core, seen most clearly in the open cut trenches on the High Street, Market Place and East Road. In all cases, a series of compacted occupation deposits, more mixed occupation deposits and layers of sand were seen. A typical sequence of deposits was modern tarmac, cobbles or chippings, over a series of layers of sand, then rich silty material with charcoal, shell, pottery and bone, usually quite compact, then sand, then a more mixed occupation deposit, then thin layers of interleaving sand and midden material over a further deep occupation deposit (illus 8). From this it can be seen that there appear to be a limited number of 'types' of deposit, although their individual make-up is somewhat different. The richest of these is the 'midden' material (although this material is unlikely to originate from an actual midden, it is similar in make-up) marked as midden deposit in illus 8 and 9 , which tends to be rich in charcoal and organic material, dark in colour and somewhat soft and greasy in texture. The layers of sand appear to have two origins; thin bands of wind-blown sand, and thicker deposits of probably deliberately dumped material. This thicker deposit often appears to be redeposited beach sand. The remaining general 'occupation deposit', marked as occupation deposit in illus 8 and 9 , tends to be far less rich in organic material than the 'midden', and much sandier in make-up. It is thought that the occupation deposits originate in the mixing of the richer compacted material with large amounts of sand.

In general, the thinner 'midden' deposits extend across large parts of the trenches, often appearing for several metres or more. They also tend to be of uniform thickness, suggesting that the deposits were deliberately spread out over time. The heavily compacted nature of some of these deposits is likely to be a result of their location along the line of roads or tracks within the burgh, as they would be trampled into rough surfaces, and this also partly explains the thinner nature of the deposits. It contrasts with the thicker mixed deposits, which must have a different origin, possibly as a result of attempting to level out uneven areas of road.

\subsubsection{Westgate}

Along Westgate, the midden deposits seen were usually only in small surviving sections, often only $0.1-0.2 \mathrm{~m}$ wide, making it difficult to identify the same continuous deposits seen further to the east. However, it is clear that the midden material that was identified in trenches immediately to the west of the junction with Church Road is far less rich and contains less organic material in comparison.

Something of a comparison can also be made with the amount of pottery present. Table 2 shows the number and types of sherds of pottery collected 


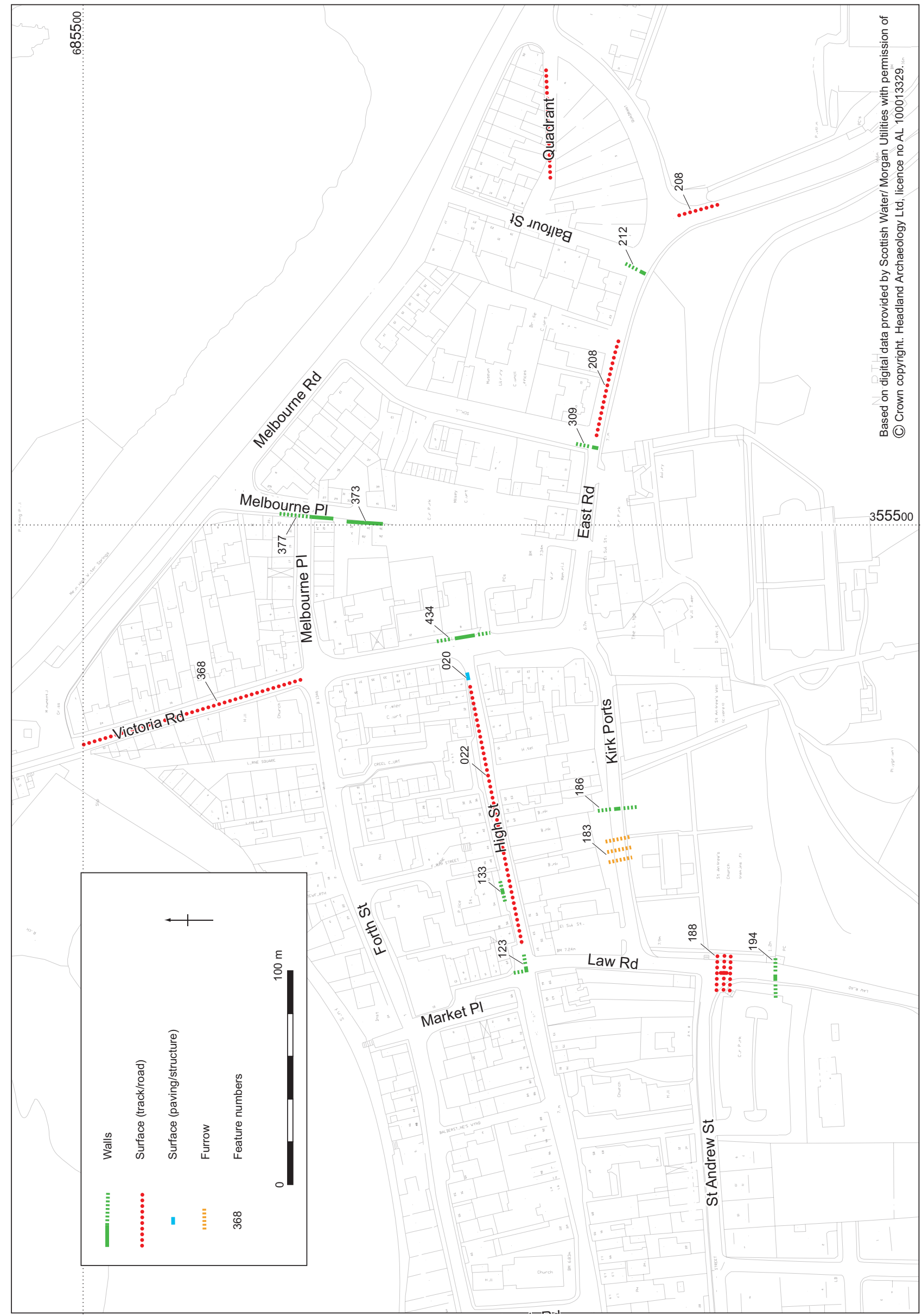

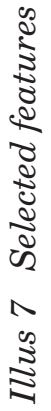




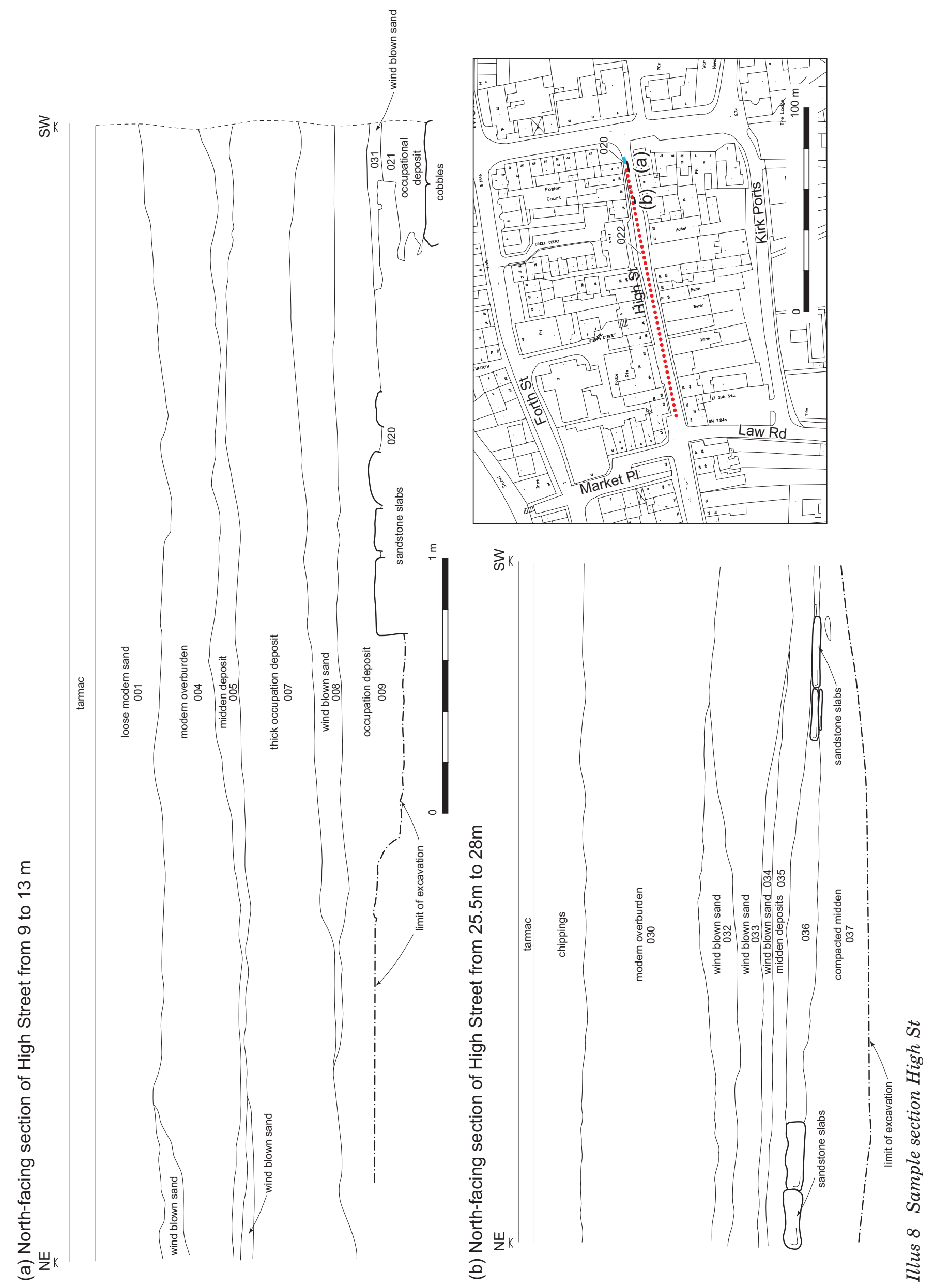


from each trench. Although some allowance must be made for the fact that the High Street trenches were open cut whilst those on Westgate were over old services, there is a stark difference between the two areas, with nearly 200 medieval sherds being recovered from the High Street and only 5 of similar date from Westgate.

\subsubsection{East Road}

A similar state of affairs was also evident to the east of the town, where extensive 'midden' deposits were also found. This was another area of open-cut trenching and the deposits seen here were clearly less rich than those in the core of the town. The sequence of deposits here is relatively similar to the High Street, with several layers of compacted material rich in charcoal and shell, wind-blown sand and deeper occupation deposits. However, the deposits are highly compacted, and a number of them appear to form a fragmented trackway lying between $0.75 \mathrm{~m}$ and $0.9 \mathrm{~m}$ below the current road surface, leading east from the burgh. The fragmentary nature of the deposit may indicate areas of heavier wear, for example where there has been wheel rutting (Dingwall 2004, 42). The highly compacted nature of the deposits both above and below this level indicates that it is likely that the material spread out along this route was routinely roughly trampled into a surface, and this more sophisticated attempt at a track (formed of compacted midden, burnt sand and small stones) may represent a more 'official' attempt.

\subsubsection{Kirk Ports}

The trenches were generally located within the extent of the carriageway of the roads, which in turn often have a long history. On Kirk Ports (a relatively recent creation) there was an opportunity to examine activities in the backlands at the rear of the High Street burgage plots. Unfortunately, the trench ran along the line of the road-widening scheme undertaken in 1994 (Hall \& Bowler 1997, 664) and cut through an upper deposit of modern road make-up material. However, at the base of the trench, three cultivation furrows (183) aligned roughly north-south were identified. These were cut into a clean redeposited sand (184), which appeared at the same level (although separated by later disturbance) as a loose garden soil (185) of probable post-medieval date. To the east of this, there are the remains of a lime-mortared wall foundation (186), which may be slightly earlier in date. It is hardly surprising that evidence of cultivation was identified in the backlands, and the wall is probably a north-south-aligned rig wall. Unfortunately, the surrounding garden soil gave no indication of types of activities taking place beyond general cultivation.

\subsubsection{Quadrant Lane}

To the east of the medieval core, trenches on Quadrant Lane identified post-medieval occupation material, again with layers of wind-blown sand and redeposited beach sand. The deposit contained large quantities of slag, and provided evidence of the foundry that stood in this area in the 19th century.

\subsubsection{Wind-blown sand}

The importance of the wind-blown sand deposits in understanding the history of the burgh should not be underestimated. The 1997 study of North Berwick (Hall \& Bowler 1997, 671) recognised the impact it had on the town, with it being likely that each winter large parts of the town would be inundated with potentially deep deposits of wind-blown sand, which may have required an amount of work to bring the ground back to cultivable quality each year. This would have been even more frequent as there were no buildings along the line of Forth Street until the early 19th century, implying there was little protection from the onshore sandstorms. It is suggested that the thicker layers of occupation material seen during the course of the watching brief could be a result of the 'working-in' of excess amounts of sand into midden material. These thicker deposits are clearly distinct from the series of thin layers of rich occupation material and wind-blown sand. Although they contain pottery and charcoal, it is in smaller amounts, and they also tend to be slightly drier and far sandier.

\subsection{Archaeological structures and features}

\subsubsection{Town walls}

In addition to the sequence of deposits, there were a number of structures identified that can be coherently related to the development of the town. Potentially the most important of these was the wall (373) seen on Melbourne Place (plate 1). This ran north-south, was $0.9 \mathrm{~m}$ wide and survived to six courses in place (all below current ground level). It was lime mortared and rendered in lime on its east face. At its southern extent, it appeared to curve to the west, towards Quality Street. A fragment of 12th-14th-century pottery was recovered from the core of the wall. The narrow nature of the trench made it difficult to identify deposits in relation to the wall, however, on its eastern side, a deep deposit of relatively clean yellow sand was identified (374), which appeared to abut it. This sand was only seen in section, so the relationship between it and the wall cannot be conclusively proven. However, it seems likely that this is a natural build-up of wind-blown sand against the external face of a substantial wall of probable late medieval or post-medieval date. This structure certainly appears to be the easternmost 


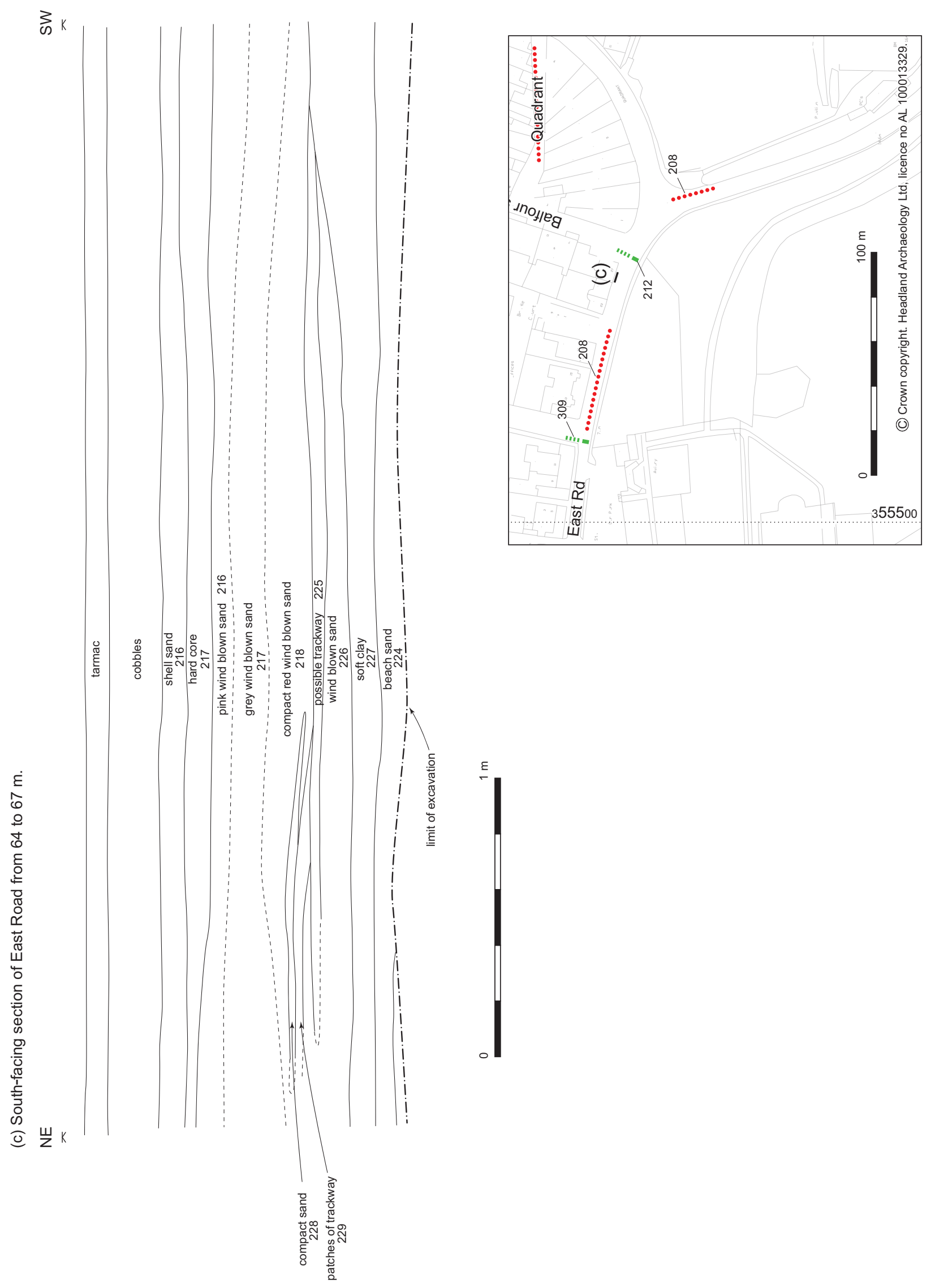

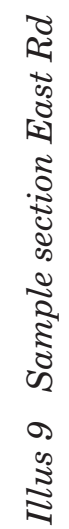




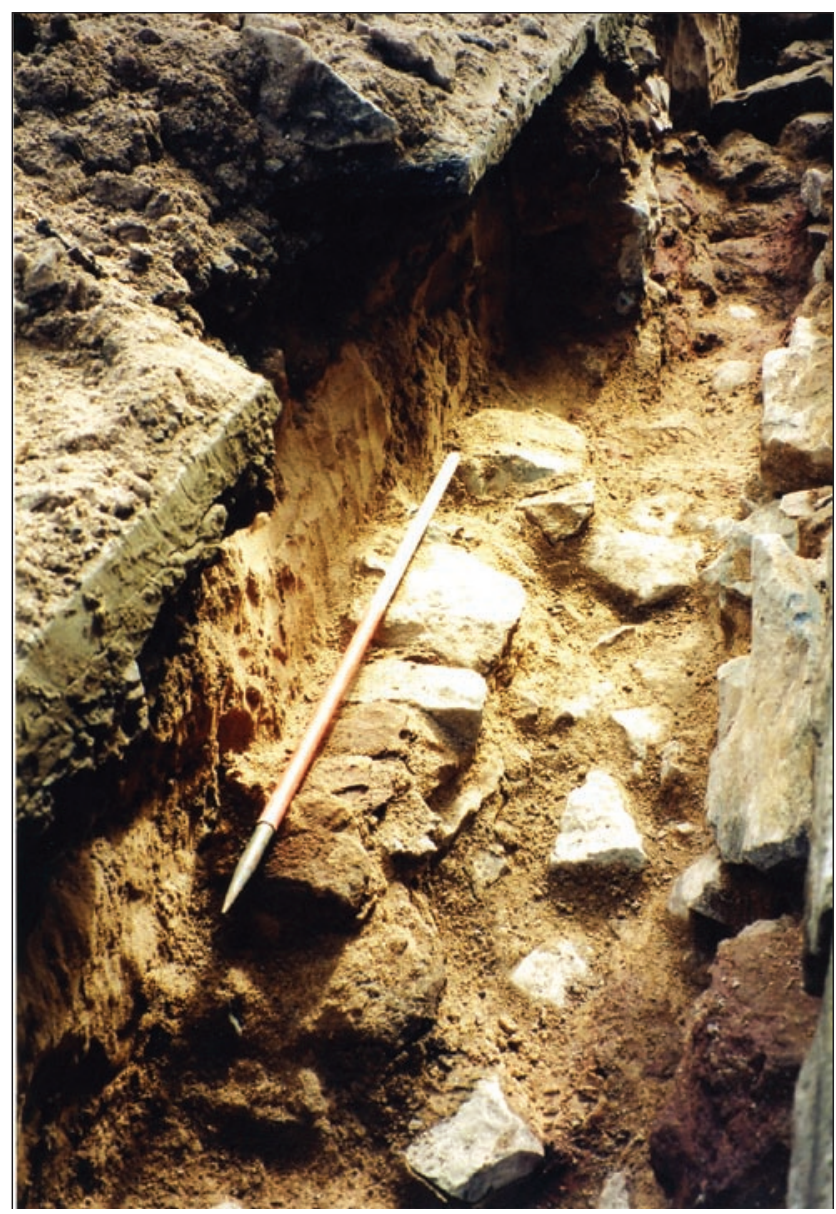

Plate 1 Wall 373

structure in the town, with nothing else between it and the sandy expanses of the east bay, and is situated within the area where such walls had previously been expected. The build of the wall would certainly be in keeping with a date before the mid 18th century, and the position fits with that shown on Roy's map of that date. This may be an indication that the official town walls referred to in the 1503 Act of Parliament were simply never built at North Berwick and that this is the 'town wall', in that it is the wall that marks the boundary of the town, rather than a specifically defensive structure.

To the south of the burgh, another wall (194) was identified on Law Road (illus 10), which again may relate to the 'town wall'. This wall was only seen in section and was of sandstone and lime mortar construction. It lined up with the southern wall of the churchyard, and may be the back wall of one of the plots to the south of the High Street, as shown on Roy's map of the mid 18th century. Again, this is not a town wall in a defensive sense, but it does appear to mark the southern extent of activity in the town.

\subsubsection{Road surfaces}

At the eastern end of the High Street, at the junction with Quality Street, a layer of red sandstone slabs
(020) was found below a series of alternating layers of midden material and wind-blown sand, at a depth of $1.2 \mathrm{~m}$ below current ground surface (illus 8). Where a small portion of the sandstone slab had been removed during excavation, a further layer of cobbles could be seen (022) underneath. Fragments of pottery dating from the 12 th to 15 th centuries were recovered from the material the slabs were set into, along with a single sherd that could be dated more specifically to the 13th or 14th centuries (table 2). The layer of sandstone slabs appears to be an area of yard associated with a building at the end of the High Street, with evidence of at least two phases of use or repair.

Immediately adjacent to the slabs and along the length of the High Street, a number of further deposits were identified at a similar depth (036 in illus 8), which while not the same material, were similarly compact, occasionally having cobbles set in them or other concentrations of compacted stones. These are interpreted as being part of a fragmented road surface, dating to the medieval period. There are further examples of compacted material, often much like decayed red sandstone in nature, in a number of the trenches further along the High Street, on Market Street and on Forth Street, all of which represent the remains of street surfaces. It is too difficult (given the fragmented nature of these deposits along with the fact that they were only seen in a series of discrete trenches) to say that they belong to the same feature or level, but they certainly represent a surface or series of surfaces dating to roughly the same period, which was used over a broad period of time and subject to damage and subsequent repair. This can be compared with the deposits seen on East Road, where there was a road surface, but formed from compacted occupation deposits rather than laid of stone. It was not until later on in the burgh's development that there was a more concerted effort to improve East Road, and the formation of a metalled surface.

The deposits on Victoria Road and leading towards the harbour also indicate the presence of a street surface. For almost the entire length of Victoria Road there was a compacted surface (368) of sandstone chips and clay, generally at a depth of $0.3 \mathrm{~m}$ to $0.4 \mathrm{~m}$ below ground level, lying over a sequence of clean and dirty wind-blown sand, and lying under a layer of mixed occupation deposit $(365,378,380)$. In the area of the harbour, deep deposits of make-up material were identified, which had previously been seen in other excavations in this area (Addyman $2000,28)$. These are thought to date to the early 19th century, when the western side of the natural rocky harbour was built up. The surface may also date to this period.

An area of rough cobbling (188) was found on Law Road at the junction with St Andrew Street. The deposits on Law Road were substantially shallower than those elsewhere in the burgh, due to the rising natural bedrock to the south. The cobbling overlay a 

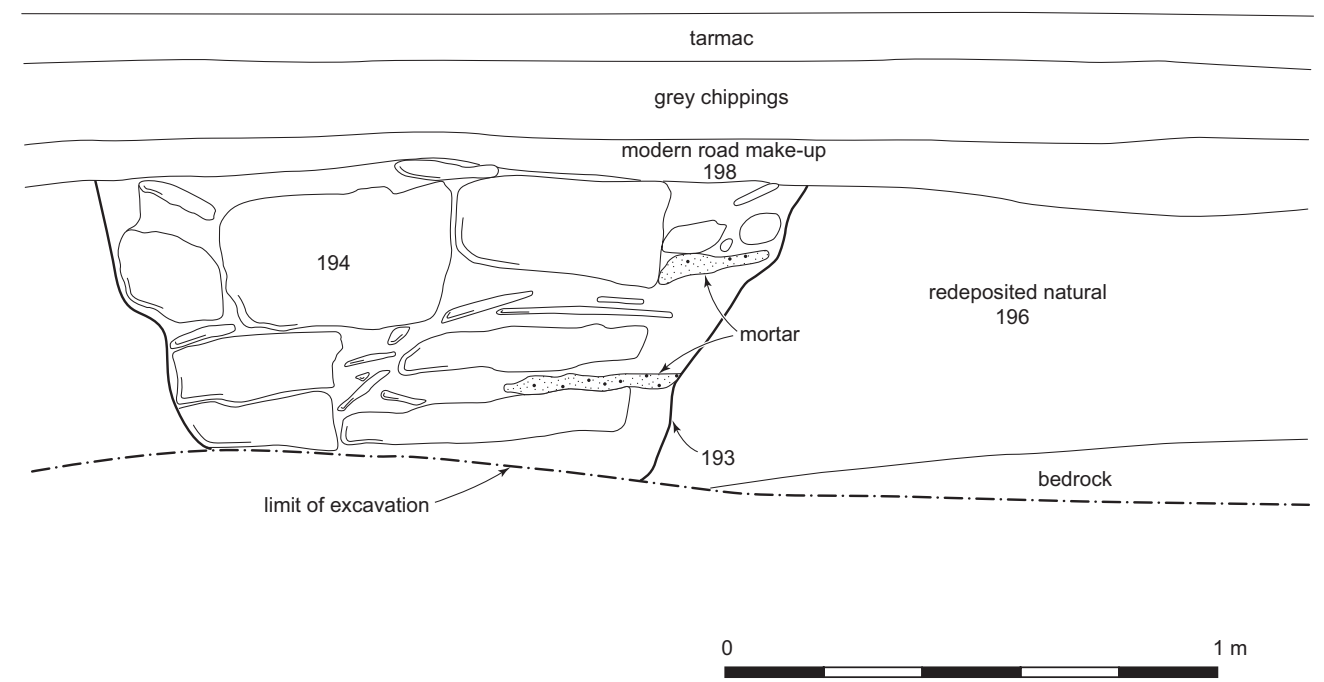

Illus 10 Wall 194

thin layer of clay material that contained charcoal, and is thought to be aligned east to west, although again it was only seen in section in a very narrow trench. The cobbling is presumed to be a surface of some sort, and to be indicative of a previous layout of the corner of St Andrew Street and Law Road. 


\section{ARTEFACTS AND THEIR DISTRIBUTION by Julie Franklin}

\subsection{Medieval pottery}

The pottery assemblage numbered 505 sherds, 318 of which were of medieval date. These were concentrated in the midden layers of Trench 1 on the High Street, with a small outlying group from Abbey Road and the Westgate, towards the lands of the Cistercian nunnery.

For the most part these sherds are small, abraded and clearly redeposited. The only exception to this is a silty deposit from Trench 41 on Market Street (Context 146), containing seven large joining sherds, making up half the base of a cooking pot. Though there are no sherds from the rest of the vessel, this deposit would appear to be less disturbed than others.

Most of the medieval sherds are of Scottish White Gritty Ware. It is generally off-white to pale buff or pale grey, with a surface often slightly darker or redder. A small proportion of sherds are reduced to a darker grey. This is typical of the kind of pottery widely produced in Scotland, particularly the southeast, between the 12th and 15th centuries (Hall 2004; Jones et al 2003). The fabric changes little over this period, though the forms and decoration present suggest the bulk of the material dates to the 13 th and 14 th centuries.

The small sherd size means there is little evidence for vessel form, though rims indicate the usual types of jars, cooking pots and jugs. Jugs most commonly have strap handles, about half of which are decorated with longitudinal grooves. The most unusual sherd is a jug handle with a large incised hump at the top handle junction, similar to the 'beards' accompanying face mask decoration (illus 11a). Similar sherds have been found at the nearby White Gritty kiln site of Colstoun, just south of Haddington (Brooks 1980; Hall 2004). In fact all the fabrics, forms, decoration and glazes seen in the North Berwick White Gritty assemblage are represented at Colstoun. It is not known how common these kilns were or how wide an area they served but it is possible Colstoun supplied North Berwick's pottery needs in the 13th and 14th centuries. Several sherds are decorated in Yorkshire-inspired styles. These include rodhandled jugs, two of which are glazed in a bright copper speckled green, iron-coloured ridges, applied scales and impressed wheat-ear motifs.

The only imports found were Yorkshire wares, with seven small Scarborough-type sherds recovered. This was the most commonly imported pottery in south-east Scotland between the mid 12th and mid 14th centuries (Farmer 1979). The lack of any other types, again, suggests a 13th and 14th century date for the bulk of the assemblage. These imports
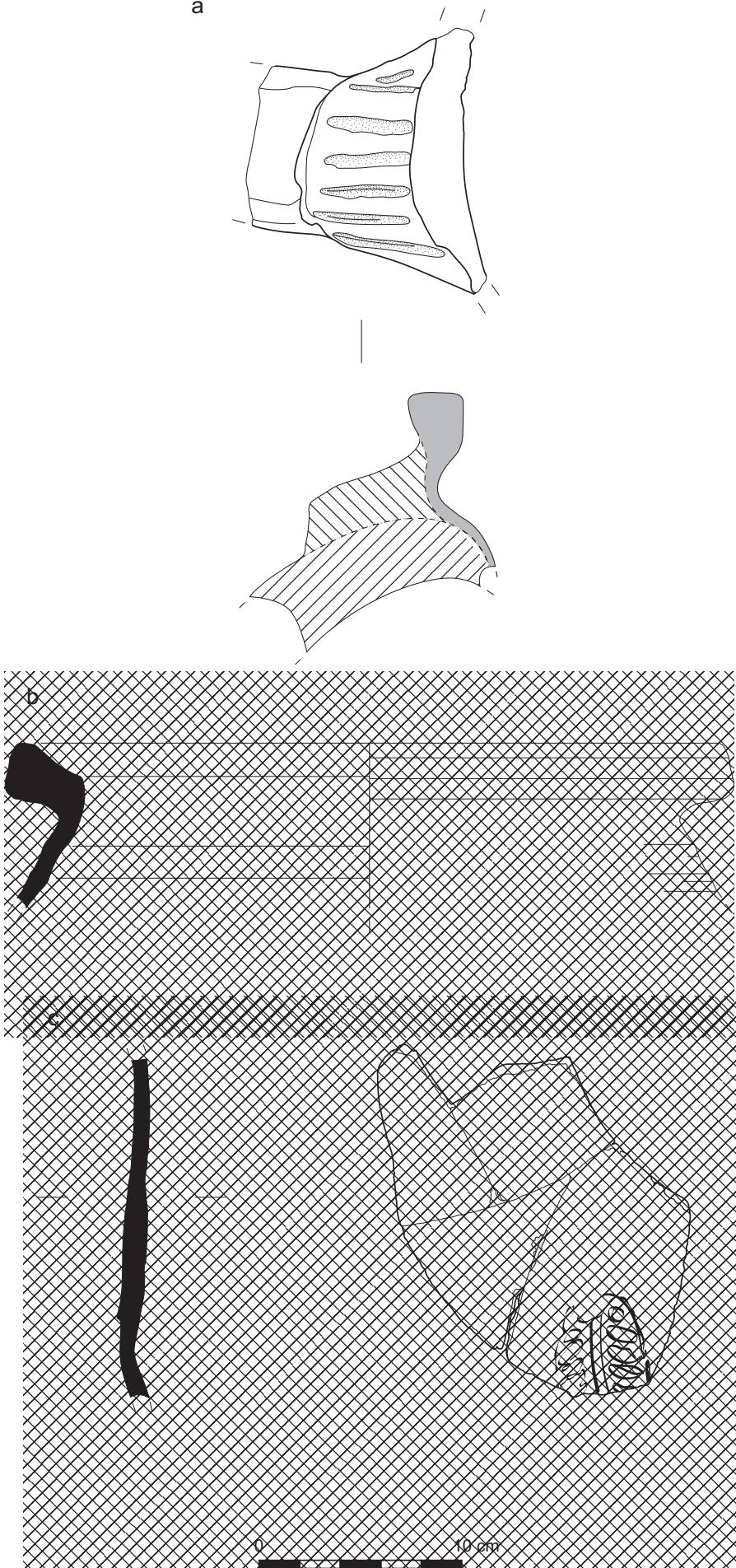

Illus 11 a) White Gritty jug rim. Incised hump at handle junction, patchy pale olive green glaze. Tr.20, unstratified; b) White Gritty jar rim. Sooted cooking pot rim with spots of yellow and copper green glaze on rim. Tr.28, unstratified; c) Reduced Gritty jug shoulder sherd. Impressed wheat-ear decoration, olive-green glaze. Tr.1, unstratified. 


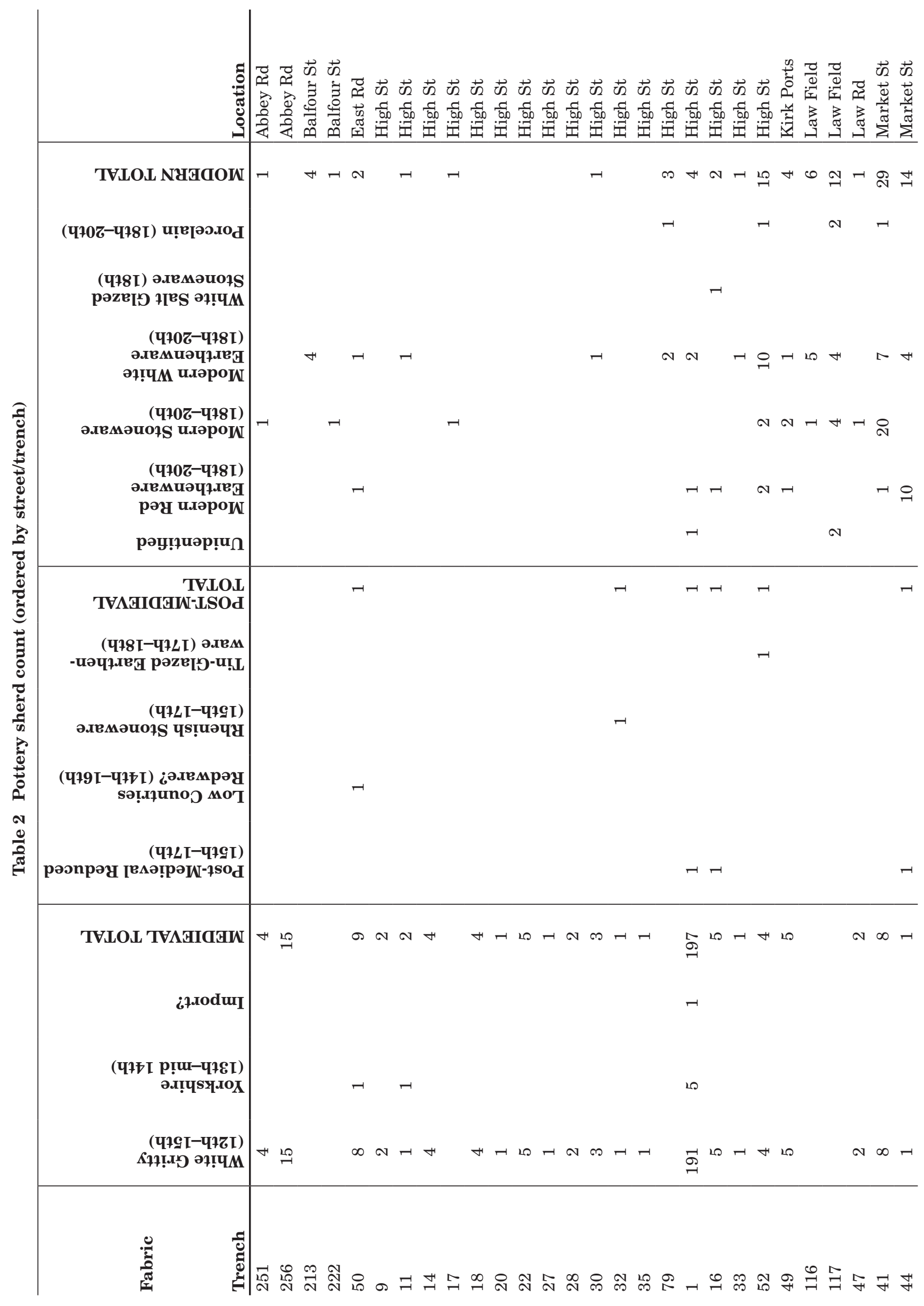




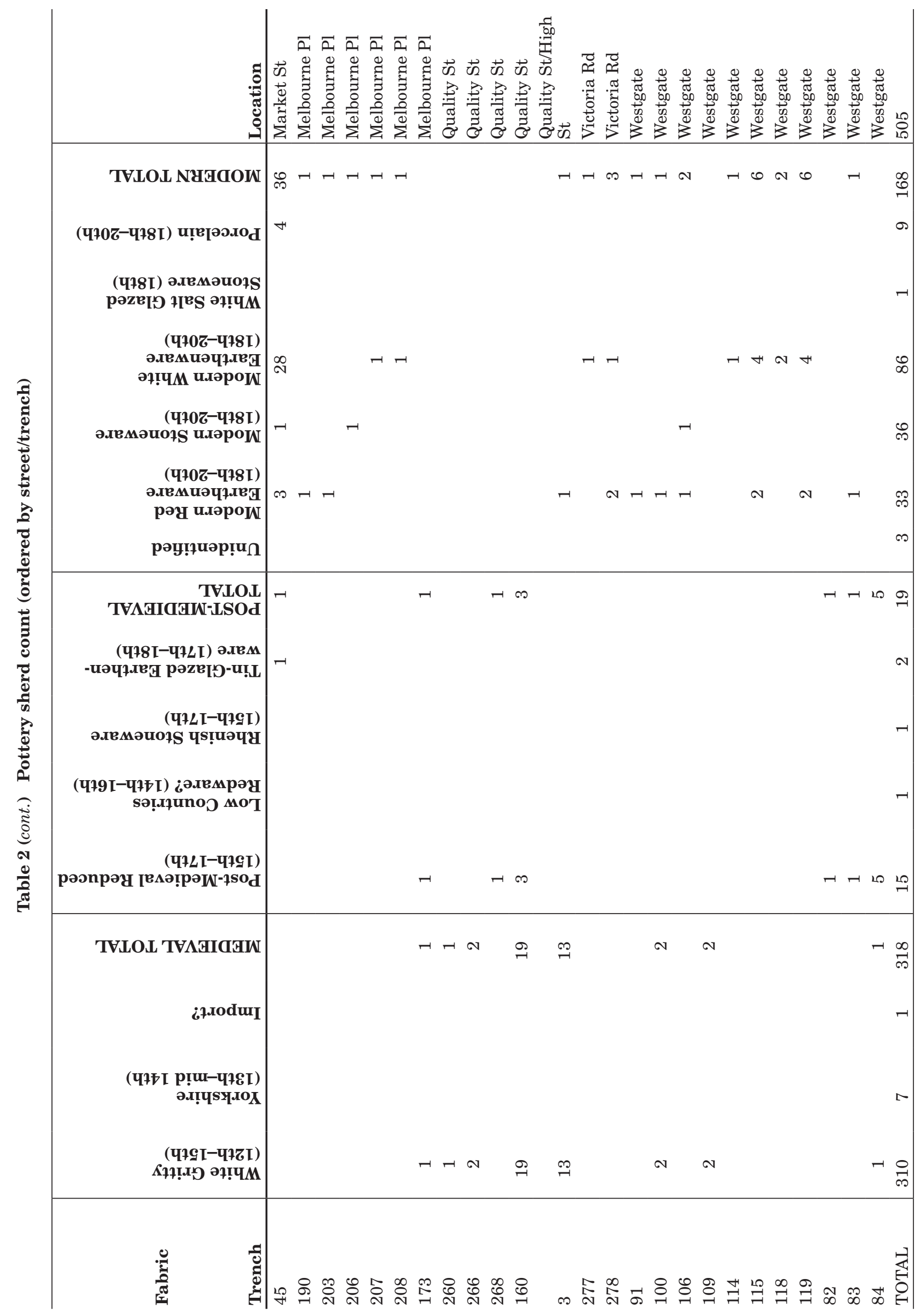


represent only $2 \%$ of the sherd count, a smaller percentage than might be expected from a port and suggests pottery may not have been directly imported into North Berwick, but was instead reaching the burgh via Edinburgh or Dunbar. The large medieval assemblage from Castle Park, Dunbar (Hall 2000) contained nearer 13\% of Yorkshire wares, though again, no other imported types.

\subsection{Medieval roof tiles}

Two sherds of medieval roof tiles, each of quite different fabric, were also found. The first, from Trench 1 on the High St, is of a sandy orange fabric with dark grey core, tempered with frequent small shell inclusions. Shell tempers are more often associated with early medieval pottery from the London area and East Anglia, and it is possible that this sherd was imported.

The second, from Trench 104 on the Westgate, is pale pink with a white core, containing frequent large white and red stone inclusions. It is more akin to the local pottery, though coarser, and may well be locally produced.
Roof tiles are known from medieval contexts from the 13th century onwards. They are not common and are assumed to have been used only for edging on the roofs of higher status buildings (Cox 1996, 724). While a high-status building on the High St is no surprise, the sherd from Westgate may be associated with part of the nunnery.

\subsection{Later pottery and finds}

There are surprisingly few finds dating to the later medieval and early post-medieval periods. There is a handful of sherds of 16th- and 17thcentury date, including a sherd of Low Countries Redware, a fragment of Rhenish stoneware and two pieces of Delft, and two fragments of clay pipe. Post-medieval finds are scattered around the High Street, but the largest group came from the Westgate.

Modern finds were more numerous, more varied and wider spread throughout the trenches. These included pottery, glass bottles, a coin, pieces of pan tile and brass door furniture. 


\section{CONCLUSIONS}

The methodology of the watching brief allowed an analysis of a wide range of deposits and structures throughout the town, providing a fairly comprehensive picture. In fact, there were very few areas within the defined core where evidence for medieval activity of some description was not recovered.

However, the limitations of this are immediately apparent in the fact that it is difficult to relate different deposits from separate trenches around the town to create a completely coherent picture.

Of the range of deposits identified, what is most interesting is probably the level of distribution of medieval material, which confirms the previously supposed limits of the medieval core. Up until now, the limits of the medieval town had been based on examination of map morphology and the knowledge that the town only expanded from this in the 19 th and 20 th centuries. We now have a body of evidence, showing exactly where the medieval deposits are present and where they are not. For example, this confirms previous theories about the level of occupation on Westgate during the medieval period and later, which appears to have been substantially less heavily occupied and used than the High Street. This contrasts with East Road, where extensive deposits appear, possibly from early on in the town's history.

Similarly, it could be suggested that the presence of a relatively continuous and maintained surface along the length of the High Street would make it a more likely candidate for the original focus within the burgh, as compared to Quality Street (previously known as Market Place/Crossgate). Admittedly, there was less opportunity to see the evidence from Quality Street, but where open trenching was present, no such surface or structure was seen.

There are also advantages and disadvantages to the location of the trenches. The street pattern of North Berwick has remained relatively consistent over the centuries, and the trenches were all located along these routes. This allowed a more uniform comparison of the deposits from different trenches, as they all related to the build-up of material along the streets. The downside of this was that as there were no trenches in the back gardens or houses, or within house plots, nothing relating to strictly domestic activity was identified. The recent excavations at 33 Forth Street indicate that evidence of individual burgage plots and related buildings may survive, but this was simply not seen within the limits of the watching brief.

The other main achievement of the work is the identification of certainly one, and possibly two, sections of wall which may be the elusive 'town wall'. If this is the case then certainly it would imply that North Berwick never embarked on building any properly defensive town walls, as it was instructed to do in the early 16 th century.

The implications for future work within both North Berwick and other small burghs which have not been subject to large-scale redevelopment are substantial. In the case of North Berwick, there is now a fairly complete body of evidence with detailed stratigraphic sequences. This can be used along with the two burgh survey works and Hall \& Bowler's update from 1997 to inform both planning decisions within the burgh and methodologies for future work. The implication for other towns is that a well planned and executed watching brief, run in close conjunction with the engineering or other appropriate contractors can produce an extensive amount of evidence about towns that would otherwise have little opportunity for development within a medieval (or earlier) core. Even the smallest holes produced evidence and the stratigraphy of deposits seen was often in the corner of a trench excavated through largely disturbed deposits. When this kind of fragmentary evidence is combined what is produced is something more than its constituent parts. 


\section{ACKNOWLEDGEMENTS}

The watching brief and post-excavation analysis and publication were funded by Scottish Water Solutions and Morgan Est. The watching brief was carried out by Kirsty Dingwall and Elizabeth Jones, assisted by Graeme Brown, Stewart Buchanan, Richard Conolly, Magnar Dalland, Sarah-Jane Haston, Colin Hewat, Mike Kimber,
Chris Lowe, Paul Masser, Jonathan Millar, Jenni Morrison and Ross Murray. The illustrations were produced by Tom Small. The project was curated by Biddy Turner Simpson for East Lothian Council. The project was managed by Chris Lowe and the author benefited from his advice and assistance in preparing this report. 


\section{REFERENCES}

Adair, J 1682 A Map of East Lothian.

Addyman, T 2000 'St Andrew's Old Church and Kirkyard, North Berwick', Discovery \& Excavation in Scotland, 27-8.

Addyman, T forthcoming 'Excavations at St Andrew's Old Church and Kirkyard, North Berwick'.

Blaeu, J 1654 Atlas of Scotland.

Brooks, C M 1980 'Medieval pottery from the kiln site at Colstoun, E Lothian', Proc Soc Antiq Scot 110 (1980), 364-403.

Cox, A 1996 'The Artefacts', in R J Coleman 'Burgage plots of medieval Perth: the evidence from excavations at Canal Street', Proc Soc Antiq Scot $126,718-24$.

Cressey, M \& Mitchell, S 2003 7-9 St Andrew Street, North Berwick, East Lothian. Building Survey \& Archaeological Evaluation. CFA unpublished client report.

Cromwell, T 1993 'Forth Street Lane, North Berwick' in Discovery \& Excavation in Scotland, 56.

Dingwall, K 2004 'Water Mains Renewal, North Berwick, East Lothian: Data Structure Report of an Archaeological Watching Brief.' Headland Archaeology unpublished client report.

Farmer, P G 1979 An Introduction to Scarborough Ware and a Reassessment of Knight Jugs. Hove.

Ferrier, W 1991 The North Berwick Story. Edinburgh.

Forrest, 1802, Map of Haddingtonshire.

Hall, D 1993 '15 Westgate, North Berwick’, Discovery \& Excavation in Scotland, 56.

Hall, D 2000 'The Pottery' in D R Perry, Castle Park Dunbar: Two Thousand Years on a Fortified Headland. Soc Antiq Scot monogr ser 16, 107-112.

Hall, D \& Bowler, D 1997 'North Berwick, East Lothian: its archaeology revisited', Proc Soc Antiq Scot 127 (1997) 659-75.

Hall, D 2004 'Excavations at the pottery production centre of Colstoun, East Lothian in 1939, 1969, 1971, 1977 and 1999/2000', Medieval Ceramics 28 (2004) 34-73.

Historic Scotland 1995 '7 Victoria Road, North Berwick', Discovery \& Excavation in Scotland, 50 .
Johnson, M 2004 'Law Road/St Andrew St, North Berwick', Discovery \& Excavation in Scotland, 45.

Jones, R; Will, R; Haggerty, G \& Hall D 2003 ‘Sourcing Scottish White Gritty ware', Medieval Ceramics 26/27, 45-84.

Lowe, C 2001 'The distribution and survival of medieval and later deposits in the medieval burgh of Crail, Fife', Tayside and Fife Archaeological Journal, vol. 7, 93-109.

Macfadyen, K 2004 'St Andrew's Old Kirk, North Berwick', Discovery \& Excavation in Scotland, 45.

Macfadyen, K 2004 'Scottish Seabird Centre, North Berwick', Discovery \& Excavation in Scotland, 45.

Mackenzie, J R 1995 'Quality Street/Melbourne Place, North Berwick' in Discovery \& Excavation in Scotland, 50.

Mitchell, S 2004 '33 Forth St, North Berwick' in Discovery \& Excavation in Scotland, 45.

New Statistical Account of Scotland 1845. Volume II. Linlithgow, Haddington, Berwick.

Ordnance Survey 1854 Ordnance Survey Haddingtonshire Sheet 2 (surveyed 1853) 1:10560.

Ordnance Survey 1894 Haddingtonshire Sheet II.12 (surveyed 1893) 1:2500.

Rains, M J \& Hall, D W (eds) 1997 Excavations in St Andrews 1980-89. A Decade of Archaeology. Tayside and Fife Archaeological Committee Monograph 1.

Roy 1747-55 Military Survey of Scotland.

Sharp, T; Greenwood, C \& Fowler, W 1844 Map of the County of Haddington.

SUAT 1998 Historic North Berwick: the archaeological implications of development. A Scottish Burgh Survey update.

Thomson, J 1820 Atlas of Scotland.

Turner Simpson, A \& Stevenson, S 1981 Historic North Berwick: The Archaeological Implications of Development. Scottish Burgh Survey. Department of Archaeology, University of Glasgow.

Yeoman, P 1999 Pilgrimage in Medieval Scotland. Batsford, London. 